\title{
Effects of Crushed Oyster Shell on Strength and Durability of Marine Concrete Containing Fly Ash and Blastfurnace Slag
}

\author{
Hai-Yan CHEN ${ }^{1}$, Leo Gu LI ${ }^{1}{ }^{*}$, Zhen-Min LAI ${ }^{1}$, Albert Kwok-Hung KWAN ${ }^{2}$, \\ Pi-Mao CHEN ${ }^{3}$, Pui-Lam NG ${ }^{2,4}$
}

\author{
${ }^{1}$ Guangdong University of Technology, 100 West Waihuan Road, Guangzhou, China \\ ${ }^{2}$ The University of Hong Kong, Pokfulam Road, Hong Kong, China \\ ${ }^{3}$ South China Sea Fisheries Research Institute, 231 Xingang West Road, Guangzhou, China \\ ${ }^{4}$ Vilnius Gediminas Technical University, Sauletekio Al. 11, Vilnius LT-10223, Lithuania
}

crossref http://dx.doi.org/10.5755/j01.ms.25.1.18772

Received 07 August 2017; accepted 09 February 2018

\begin{abstract}
A large quantity of oyster shell is generated every year in coastal regions. Instead of being dumped as waste, after crushing or grinding, oyster shell may be recycled for use in concrete. Herein, the use of crushed oyster shell (COS) in conjunction with fly ash (FA) and blastfurnace slag (BS) to produce marine concrete was studied. By varying the COS, FA and BS contents in the marine concrete, the combined effects of COS, FA and BS on the cube compressive strength, water penetration, cyclic wetting-drying chloride attack and long-term seawater attack resistances were evaluated. The results showed that the addition of proper amounts of COS, FA and BS has positive effects on the strength and durability of marine concrete, but excessive COS may have negative effects. Hence, the combined addition of COS, FA and BS up to a certain optimum COS content is a promising way of producing a higher performance and greener marine concrete. Keywords: oyster shell, blast furnace slag, fly ash, green concrete, marine concrete.
\end{abstract}

\section{INTRODUCTION}

The utilization of waste materials in the production of concrete so as to recycle the waste, reduce cement and aggregate consumptions and improve concrete performance has become a popular research topic [1-5]. Particularly, the industrial waste including fly ash (FA) and blastfurnace slag (BS) are nowadays commonly used as supplementary cementitious materials for partial replacement of cement [6-14]. In fact, FA and BS have become indispensable ingredients for the production of not only conventional concrete, but also high-performance concrete.

Among the various solid wastes, oyster shell (the calcareous shell of oyster), which is a waste from fishery and aquaculture, is probably amongst the least explored for possible use in concrete production. It is composed mainly of $\mathrm{CaCO}_{3}$ (about $96 \%$ ) and trivial amounts of some other minerals, as reported by Yoon et al. [15]. The major elements are calcium (37.4\%), sodium $(0.6 \%)$ and magnesium $(0.3 \%)$, as reported by Kwon et al. [16]. Taking the example of China, approximately 3 million tons of oyster shell is produced in the coastal regions every year [17]. However, despite a large quantity of oyster shell being produced worldwide, only a very small amount is recycled and used as handicrafts, fertilizer or additive in food [18-21]. Instead, most of the oyster shell is just dumped, causing hygienic and environmental problems.

In recent years, some researchers have directed their attention to the potential use of seashell in concrete. For instance, Yang et al. used crushed oyster shell as fine

\footnotetext{
* Corresponding author. Tel.: +86-020-39322527; fax: +86-020-

39322511. E-mail address: ligu@gdut.edu.cn (L.G. Li)
}

aggregate substitute and found that this has positive effect on the early strength, slight negative effect on the elastic modulus, and little effect on the freezing and thawing, carbonation, chemical and penetration resistances of concrete [22, 23]. Muthusamy and Sabri observed that the use of cockle shell as coarse aggregate replacement could reduce the workability due to its angular shape and rough texture [24]. Nguyen et al. used a seashell by-product as coarse aggregate replacement to produce pervious concrete paver and noted that this could improve the porosity and reduce the bulk density [25]. Olivia et al. used ground cockle shell as cement replacement and found that the concrete so produced had lower compressive strength but higher tensile and flexural strengths than normal concrete [26]. Li et al. successfully used oyster shell ash to replace lime in the production of unfired bricks [17]. Eo and Yi tried to applied oyster shell as aggregate substitution to produce lightweight concrete and hollow concrete blocks [27]. Martínez-García et al. demonstrated that by heattreatment at $135^{\circ} \mathrm{C}$ for $30 \mathrm{~min}$, mussel shell can be used as aggregate, and the replacement rate for fine or coarse aggregate can be up to $25 \%$ [28].

Being readily available in many coastal regions, oyster shell should have a high potential for use in the production of marine concrete. However, some researchers have found that with crushed oyster shell (COS) added, the water penetration and chloride resistances of the concrete would decrease as the COS content increases [29]. Hence, it is suggested herein that it is better to add COS together with FA and BS for the following reasons: (1) FA and BS can improve the durability performance of marine concrete [30-35] so as to compensate for the possible adverse effects of COS; (2) since COS, FA and BS are all from 
wastes sources, the utilization of COS, FA and BS can produce a greener marine concrete to conserve the environment; and (3) the use of COS can reduce the cost of concrete production, especially in remote offshore regions or islands. However, there is little research on marine concrete containing COS, FA and BS.

In the study presented herein, COS was added together with FA and BS to produce marine concrete mixes with varying COS content, $(\mathrm{FA}+\mathrm{BS}$ ) content, and $\mathrm{FA} / \mathrm{BS}$ ratio. These concrete mixes were subjected to cube strength test, water penetration test, cyclic wetting-drying chloride attack test, long-term seawater attack test and chloride content test to investigate the effects of COS, FA and BS on the strength and durability of marine concrete, and to find out the optimum mix proportions for best overall performance. This research is the first stage of a longer term study on the exploitation of oyster shell in marine concrete production in coastal and offshore regions. At a later stage, the oyster shell will be ground to different fineness to produce oyster shell fines for use as cementitious materials replacement or cementitious paste replacement.

\section{EXPERIMENTAL DETAILS}

\subsection{Materials}

In this study, cement, fly ash (FA) and blastfurnace slag (BS) provided by local suppliers in China were used as the cementitious materials. The cement used was an ordinary Portland cement of strength class $42.5 \mathrm{R}$ with a relative density of 3.08, whereas the FA and BS used had relative densities of 2.33 and 2.66 , respectively. In the concrete mix design, both the FA and BS were added as equal weight replacements of cement.

Regarding the aggregates, river sand (RS) with a relative density of 2.58 and a fineness modulus of 2.60 was used as the fine aggregate and crushed granite rock with a relative density of 2.67 and particle size ranging from 5 to $20 \mathrm{~mm}$ was used as the coarse aggregate. In this study, the oyster shell to be recycled for use in concrete was provided by South China Sea Fisheries Research Institute. It was first heated at $105^{\circ} \mathrm{C}$ for 2 hours and then crushed to a particle size of about 1 to $2 \mathrm{~mm}$ to become crushed oyster shell (COS). It has been measured to have a relative density of 2.14. In the concrete mix design, the COS was added as an equal weight replacement of RS.

A laser diffraction particle size analyzer (Beckman Coulter LS 13 320) was used to measure the particle size distributions of the cement, FA and BS, and the particle size distributions so obtained are plotted in Fig. 1. On the other hand, the mechanical sieving method was used to measure the particle size distributions of the aggregates, and the particle size distributions so obtained are plotted in Fig. 2. From these two figures, it can be observed that the particle size increased in the order of FA to BS to cement, and RS to COS to coarse aggregate.

The RS, coarse aggregate and COS were measured to have moisture contents of $0.21 \%, 0.11 \%$ and $0.30 \%$, respectively, and water absorptions of $1.10 \%, 1.04 \%$ and $10.48 \%$, respectively. It should be noted that the water absorption of the COS is particularly high; such high water absorption had been allowed for in the concrete mix design. Nevertheless, such high water absorption of the COS should play a positive role in providing internal curing.

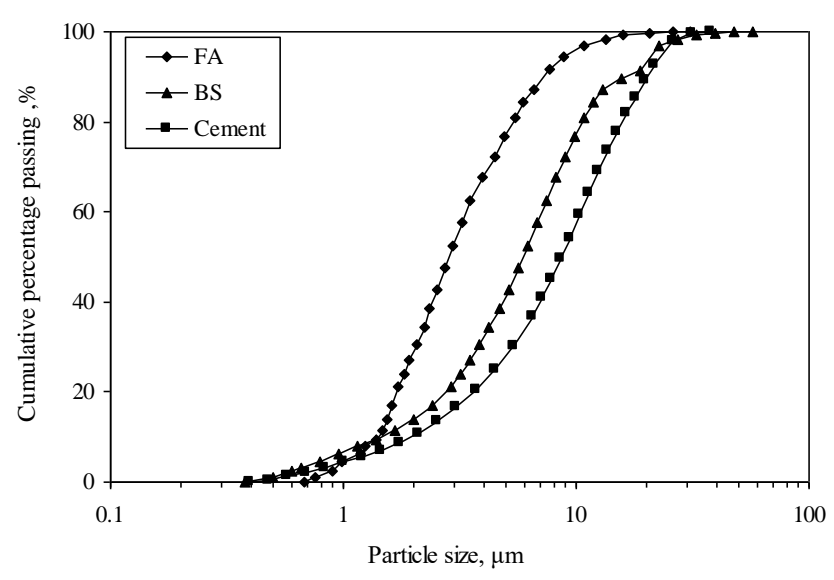

Fig. 1. Particle size distributions of cement, FA and BS

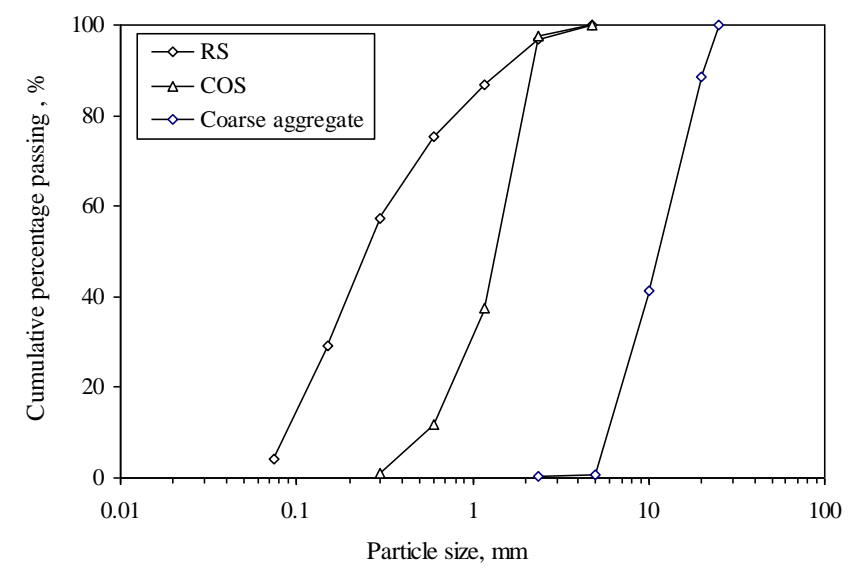

Fig. 2. Particle size distributions of RS, COS and coarse aggregate

For the cement, FA, BS and COS, a scanning electron microscopy (SEM) test via a Hitachi S-3400N-II was used to study the micro-morphology and a X-ray diffraction (XRD) test via a Rigaku D/MAX-Ultima IV was used to determine the chemical composition. The SEM images and XRD patterns of cement, FA, BS and COS are presented in Fig. 3 to Fig. 6, respectively. From the SEM images, it is observed that the cement, BS and COS particles are angular in shape due to the crushing or grinding process in their production, whereas the FA particles are spherical in shape because of their formation in hot exhaust gas environment. From the XRD patterns, it is obvious that the cement is composed mainly of $\mathrm{C}_{2} \mathrm{~S}, \mathrm{C}_{3} \mathrm{~S}$ and various kinds of oxides $\left(\mathrm{SiO}_{2}, \mathrm{CaO}, \mathrm{Al}_{2} \mathrm{O}_{3}, \mathrm{Fe}_{2} \mathrm{O}_{3}\right.$ and $\left.\mathrm{MgO}\right)$, the FA and $\mathrm{BS}$ are composed of $\mathrm{C}_{2} \mathrm{~S}$ and various kinds of oxides $\left(\mathrm{SiO}_{2}, \mathrm{CaO}, \mathrm{Al}_{2} \mathrm{O}_{3}\right.$ and $\left.\mathrm{Fe}_{2} \mathrm{O}_{3}\right)$, and the $\mathrm{COS}$ is composed mainly of $\mathrm{CaCO}_{3}$.

Lastly, a third-generation, polycarboxylate - based superplasticizer (SP) with a solid mass content of $18 \%$ and a relative density of 1.07 was added to the concrete mixes. It is a commonly used SP for the production of highperformance concrete. 


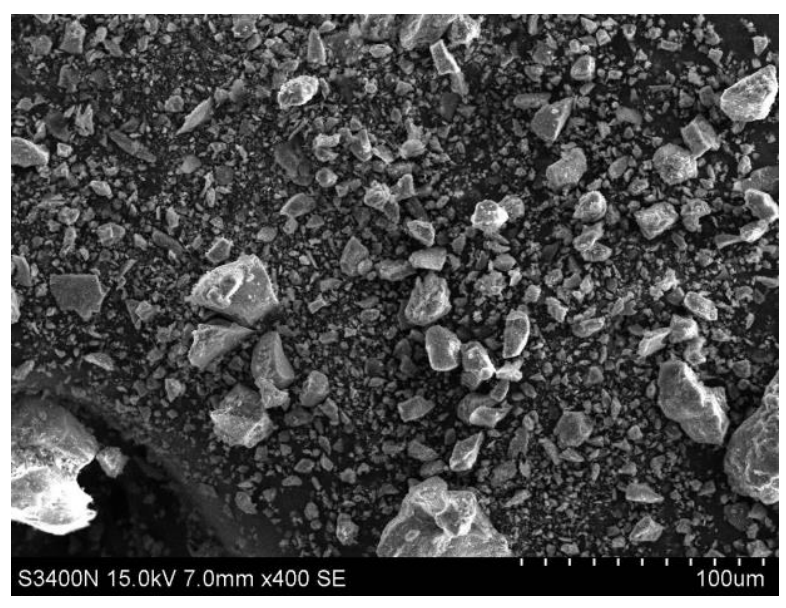

a

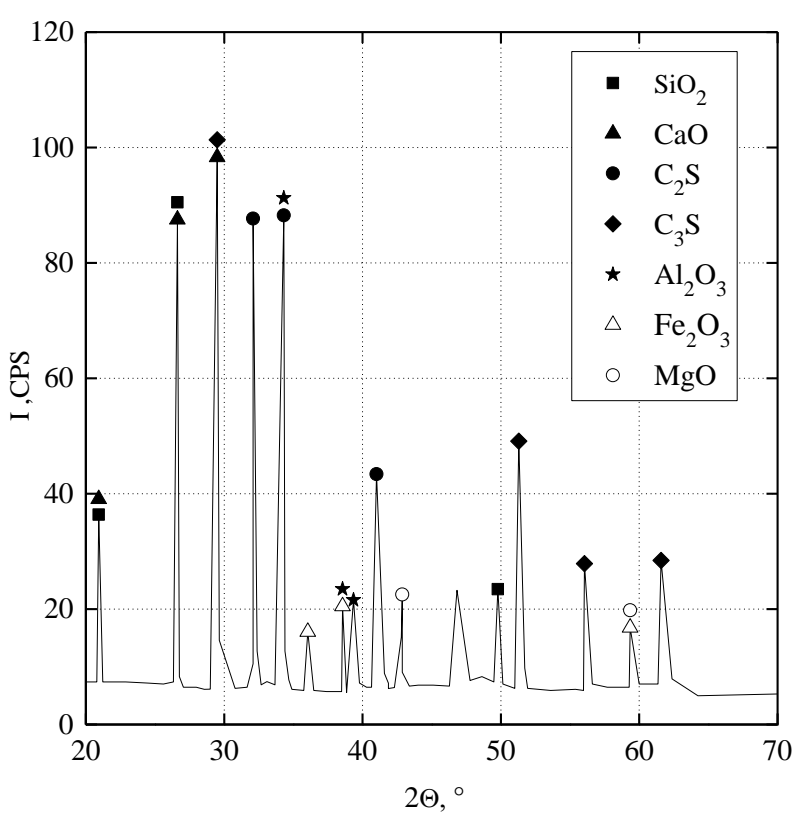

$\mathrm{b}$

Fig. 3. SEM image and XRD pattern of cement: $a$-SEM image of cement; $b-X R D$ pattern of cement

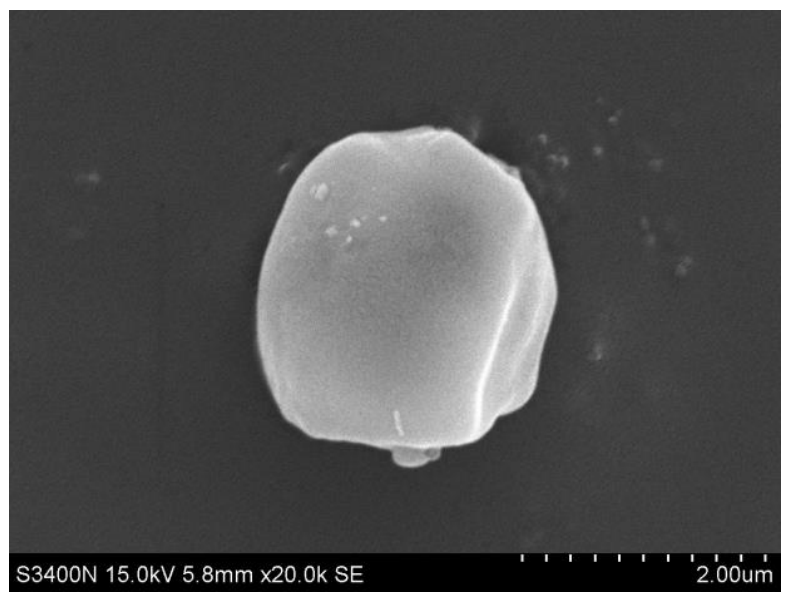

a

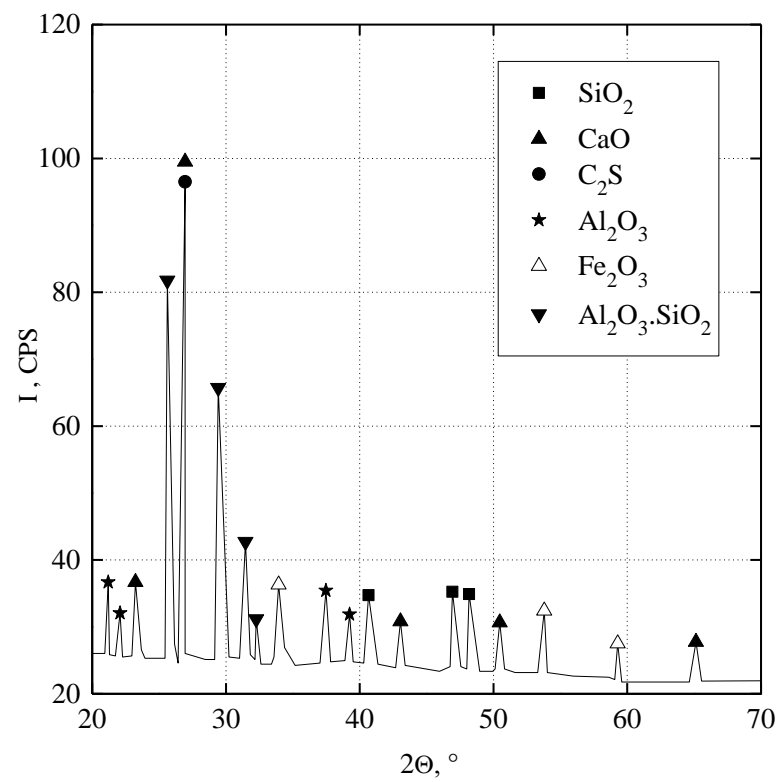

b

Fig. 4. SEM image and XRD pattern of FA: $a-$ SEM image of FA; $b$-XRD pattern of FA

\subsection{Mix proportions}

The concrete mix design was based on grade C40 normal concrete, in which the water/cementitious material (W/CM) ratio was set at 0.33 , and the mass contents of cementitious materials (cement $+\mathrm{FA}+\mathrm{BS}$ ), fine aggregate $(\mathrm{RS}+\mathrm{COS})$ and coarse aggregate were fixed at 460, 740 and $1065 \mathrm{~kg} / \mathrm{m}^{3}$, respectively. On the other hand, the SP dosage (liquid mass of SP expressed as a percentage by mass of total cementitious materials) was fixed at $2 \%$. The testing program was divided into two phases and in each phase, one series of concrete mix was tested.

In Phase I, to investigate the effects of the three mix parameters, COS content, (FA + BS) content and FA/BS ratio, on the strength and durability of concrete, one concrete mix without COS, FA and BS was set as a control mix for comparison, and nine other concrete mixes with the three mix parameters set according to the 3-factor orthogonal experimental design method [36] were produced for testing, as depicted in Table 1.

Table 1. Factors and levels of orthogonal experimental design in Phase I

\begin{tabular}{|c|c|c|c|}
\hline Level & $\begin{array}{c}\text { Factor A: } \\
\text { COS } \\
\text { content, } \%\end{array}$ & $\begin{array}{c}\text { Factor B: } \\
\text { (FA + BS) } \\
\text { content, } \%\end{array}$ & $\begin{array}{c}\text { Factor C: } \\
\text { FA/BS } \\
\text { ratio }\end{array}$ \\
\hline 1 & 5 & 10 & 0.5 \\
\hline 2 & 10 & 20 & 1.0 \\
\hline 3 & 20 & 30 & 2.0 \\
\hline
\end{tabular}




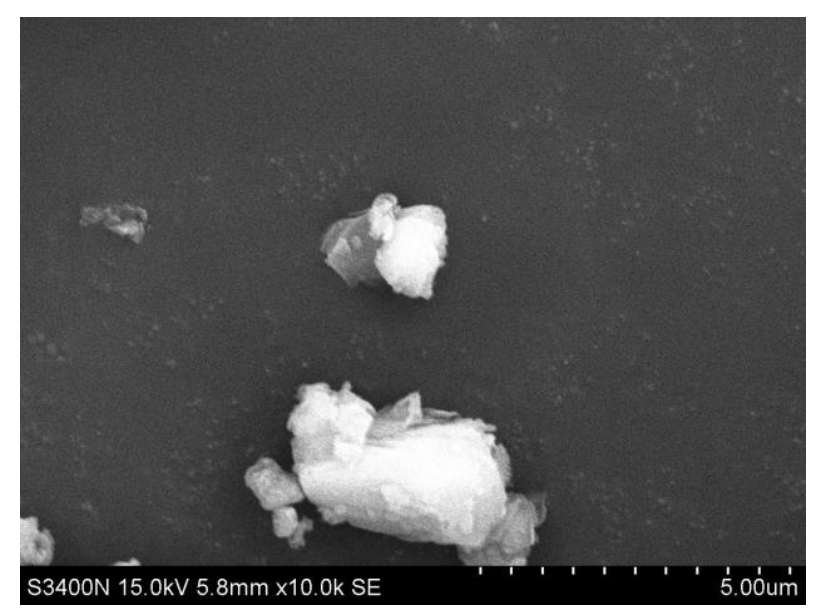

a

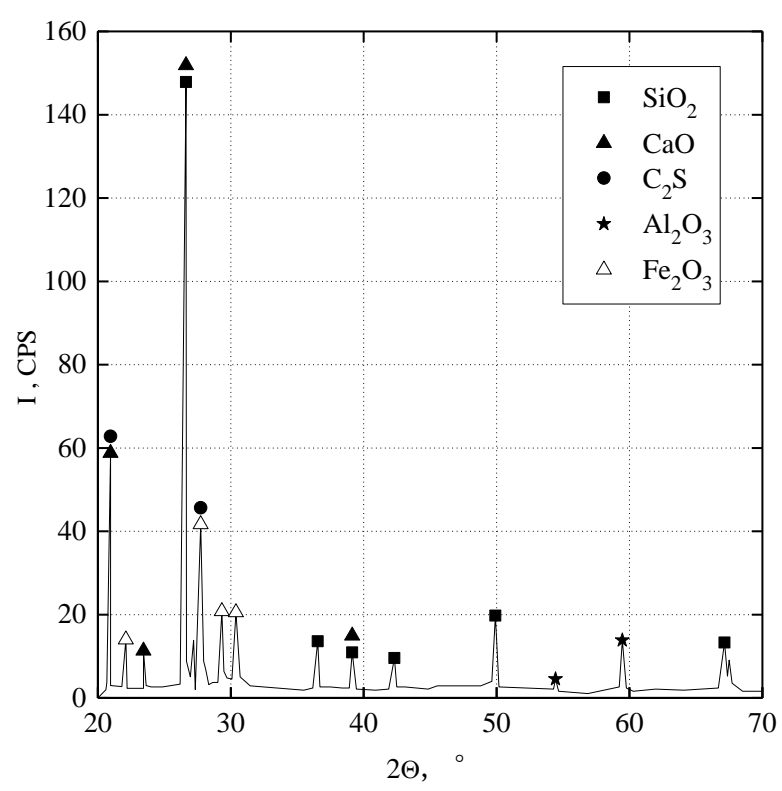

b

Fig. 5. SEM image and XRD pattern of BS: $a-$ SEM image of BS; $b$-XRD pattern of BS

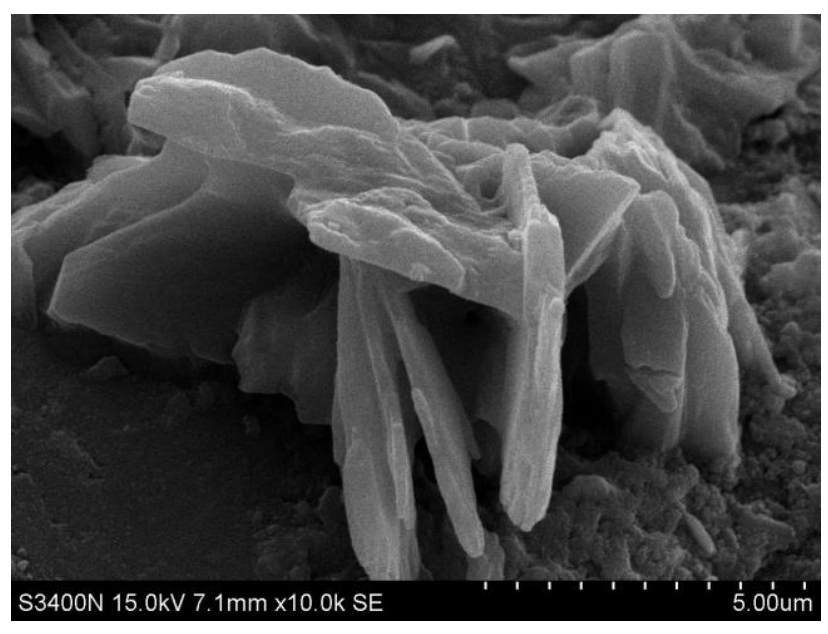

a

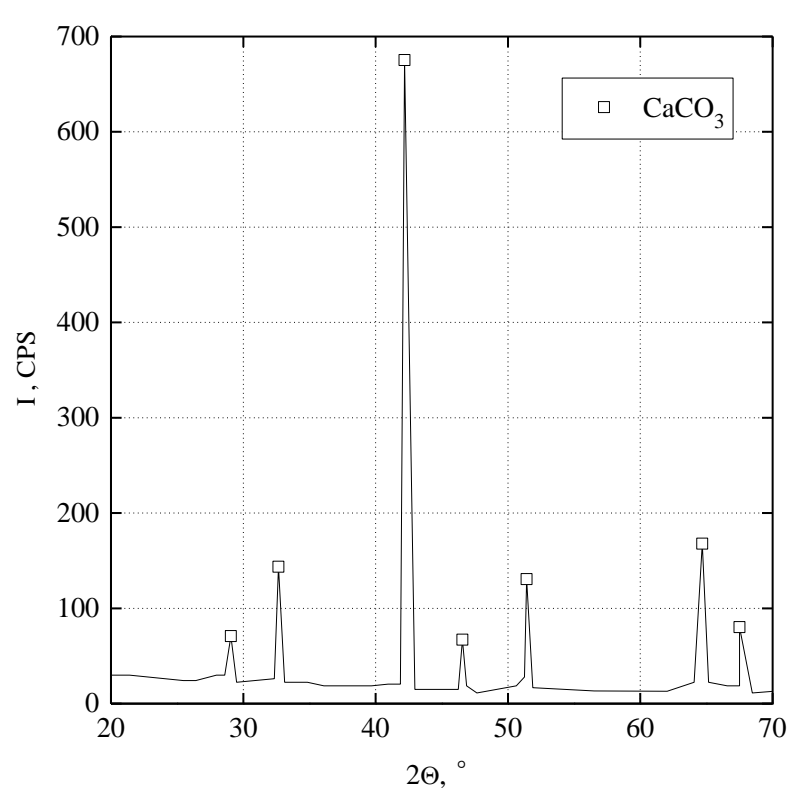

b

Fig. 6. SEM image and XRD pattern of COS: a - SEM image of COS; $b$ - XRD pattern of COS

Among the three mix parameters: factor A, the COS content expressed as a percentage by mass of total fine aggregate, was set at $5 \%, 10 \%$ or $20 \%$; factor $\mathrm{B}$, the (FA + BS) content expressed as a percentage by mass of total cementitious materials, was set at $10 \%, 20 \%$ or $30 \%$; and factor $\mathrm{C}$, the $\mathrm{FA} / \mathrm{BS}$ ratio by mass, was set at $0.5,1.0$ and 2.0 .

The control mix was identified as $\mathrm{C} 40$, whereas the other nine concrete mixes were identified as $\mathrm{C}-\mathrm{X}-\mathrm{Y}-\mathrm{Z}$, in which $\mathrm{C}$ denotes concrete, $\mathrm{X}$ denotes the level of factor $\mathrm{A}$, $\mathrm{Y}$ denotes the level of factor $\mathrm{B}$ and $\mathrm{Z}$ denotes the level of factor C. For each factor, three levels were defined as tabulated in Table 1. Details of the concrete mix proportions are presented in Table 2.

In Phase II, to further investigate the effects of COS content on the strength and durability of concrete and find out the optimum COS content, one concrete mix without
COS, FA and BS added was set as a control mix for comparison, and six other concrete mixes with the $(\mathrm{FA}+\mathrm{BS})$ content fixed at $20 \%$, the FA/BS ratio fixed at 2.0 but the COS content varying among $0 \%, 4 \%, 6 \%$, $8 \%, 10 \%$ and $12 \%$ were produced for testing. The control mix was identified as $\mathrm{C} 40$, whereas the other six concrete mixes were identified as $\mathrm{C}-\mathrm{K}$, in which $\mathrm{C}$ denotes concrete and $\mathrm{K}$ denotes the COS content, expressed as a percentage by mass of total fine aggregate. Details of the concrete mix proportions are presented in Table 3 .

\subsection{Cube strength test}

From each concrete mix, $150 \mathrm{~mm}$ cubes were made by placing the concrete mix into cube moulds, inserting a poker vibrator for compaction and covering the top surface of each mould with a plastic sheet. 
Table 2. Mix proportions of concrete mixes in Phase I

\begin{tabular}{|c|c|c|c|c|c|c|c|c|}
\hline Mix no. & Water, $\mathrm{kg} / \mathrm{m}^{3}$ & Cement, $\mathrm{kg} / \mathrm{m}^{3}$ & $\mathrm{FA}, \mathrm{kg} / \mathrm{m}^{3}$ & $\mathrm{BS}, \mathrm{kg} / \mathrm{m}^{3}$ & $\mathrm{RS}, \mathrm{kg} / \mathrm{m}^{3}$ & $\mathrm{COS}, \mathrm{kg} / \mathrm{m}^{3}$ & $\begin{array}{c}\text { Coarse } \\
\text { aggregate, } \\
\mathrm{kg} / \mathrm{m}^{3}\end{array}$ & $\begin{array}{c}\mathrm{SP}, \mathrm{kg} / \mathrm{m}^{3} \\
\text { C40 }\end{array}$ \\
\hline 153 & 460 & 0 & 0 & 740 & 0 & 1065 & 8.6 \\
\hline C-1-1-1 & 153 & 414 & 15 & 31 & 703 & 37 & 1065 & 8.6 \\
\hline C-1-2-2 & 153 & 368 & 46 & 46 & 703 & 37 & 1065 & 8.6 \\
\hline C-1-3-3 & 153 & 322 & 92 & 46 & 703 & 37 & 1065 & 8.6 \\
\hline C-2-1-2 & 153 & 414 & 23 & 23 & 666 & 74 & 1065 & 8.6 \\
\hline C-2-2-3 & 153 & 368 & 61 & 31 & 666 & 74 & 1065 & 8.6 \\
\hline C-2-3-1 & 153 & 322 & 46 & 92 & 666 & 74 & 1065 & 8.6 \\
\hline C-3-1-3 & 153 & 414 & 31 & 15 & 592 & 148 & 1065 & 8.6 \\
\hline C-3-2-1 & 153 & 368 & 31 & 61 & 592 & 148 & 1065 & 8.6 \\
\hline C-3-3-2 & 153 & 322 & 69 & 69 & 592 & 148 & 1065 & 8.6 \\
\hline
\end{tabular}

Table 3. Mix proportions of concrete mixes in Phase II

\begin{tabular}{|c|c|c|c|c|c|c|c|c|}
\hline Mix no. & Water, $\mathrm{kg} / \mathrm{m}^{3}$ & Cement, $\mathrm{kg} / \mathrm{m}^{3}$ & $\mathrm{FA}, \mathrm{kg} / \mathrm{m}^{3}$ & $\mathrm{BS}, \mathrm{kg} / \mathrm{m}^{3}$ & $\mathrm{RS}, \mathrm{kg} / \mathrm{m}^{3}$ & $\mathrm{COS}, \mathrm{kg} / \mathrm{m}^{3}$ & $\begin{array}{c}\text { Coarse } \\
\text { aggregate, } \\
\mathrm{kg} / \mathrm{m}^{3}\end{array}$ & $\begin{array}{c}\mathrm{SP}, \mathrm{kg} / \mathrm{m}^{3} \\
\text { C40 }\end{array}$ \\
\hline C-0 & 153 & 460 & 0 & 0 & 740 & 0 & 1065 & 8.6 \\
\hline C-5 & 153 & 368 & 61 & 31 & 740 & 0 & 1065 & 8.6 \\
\hline C-6 & 153 & 368 & 61 & 31 & 703 & 37 & 1065 & 8.6 \\
\hline C-8 & 153 & 368 & 61 & 31 & 695 & 45 & 1065 & 8.6 \\
\hline C-10 & 153 & 368 & 61 & 31 & 680 & 60 & 1065 & 8.6 \\
\hline C-12 & 153 & 368 & 61 & 31 & 666 & 74 & 1065 & 8.6 \\
\hline
\end{tabular}

The cubes were then stored indoor at a temperature of $24 \pm 2{ }^{\circ} \mathrm{C}$, demoulded at one day after casting and cured in lime-saturated water at a temperature of $27 \pm 2{ }^{\circ} \mathrm{C}$ until the time of testing. Finally, the cubes were tested at the specified ages for their compressive strengths.

\subsection{Water penetration test}

The water penetration resistance of each concrete mix was tested using the water penetration tester stipulated in the Chinese Standard GB/T 50082-2009 [37]. To perform the test, three conical specimens, each with a base diameter of $185 \mathrm{~mm}$, a top diameter of $175 \mathrm{~mm}$ and a height of $150 \mathrm{~mm}$, were cast from the concrete mix, moist cured for 28 days and then air dried for 1 day. After drying, the specimens were sealed on the side surfaces with melted paraffin and then quickly transferred into the moulds in the water penetration tester. When the paraffin had completely solidified, the tester was turned on and water pressure was applied at the bottom of the moulds. The water pressure was maintained at $1.2 \pm 0.05 \mathrm{MPa}$ for 24 hours. Upon completion, the specimens were removed from the moulds and each split into two halves. The water marks were identified and the average depth of the water marks was taken as the water penetration depth.

\subsection{Cyclic wetting-drying chloride attack test}

To simulate alternate wetting-drying chloride attack, a cyclic wetting-drying chloride attack testing machine was designed and built by the Guangdong University of Technology. As shown in Fig. 7, this machine consists of three parts: a testing chamber, a water tank and a control console. To perform the chloride attack test, three $400 \mathrm{~mm} \times 300 \mathrm{~mm} \times 50 \mathrm{~mm}$ panel specimens were cast from each concrete mix. After moist curing for 28 days, the panel specimens were each sealed at five faces with epoxy coating, leaving just one $400 \mathrm{~mm} \times 300 \mathrm{~mm}$ face exposed to ensure one-way chloride attack. After coating, the panel specimens were placed into the testing chamber and subjected to the cyclic wetting-drying chloride attack in 24-hour cycles for 90 days. During every 24-hour wettingdrying cycle, $3.5 \%$ sodium chloride solution at $40{ }^{\circ} \mathrm{C}$ was first pumped from the water tank to the testing chamber to immerse the concrete specimens for 8 hours. Then, the sodium chloride solution was pumped back to the water tank and hot air at $40{ }^{\circ} \mathrm{C}$ was blown onto the concrete specimens to dry them for 16 hours. After the 90 days of cyclic chloride attack, each panel specimen was tested for the chloride profile across the depth.

\subsection{Long-term seawater attack test}

To simulate long-term seawater attack, a field test of immersing concrete specimens into the seawater was carried out. Six $150 \mathrm{~mm}$ cubes and three $400 \mathrm{~mm} \times 300 \mathrm{~mm} \times 50 \mathrm{~mm}$ panels were made from each concrete mix. After curing for 28 days, three cubes were tested for their cube strengths. At the same time, the three panels were each sealed at five faces with epoxy coating, leaving just one $400 \mathrm{~mm} \times 300 \mathrm{~mm}$ face uncoated to ensure one-way seawater attack. Subsequently, the remaining three cubes and the three panels were transferred to an artificial reef managed by South China Sea Fisheries Research Institute located in Daya Bay, Huizhou, China, and immersed into the sea to a depth of $5.5 \mathrm{~m}$ for 350 days (as shown in Fig. 8). The seawater has been tested to have a salinity of $30.26 \%$, $\mathrm{pH}$ of 7.25 , dissolved oxygen content of $5.96 \mathrm{mg} / \mathrm{L}$ and conductivity of $47.26 \mathrm{mS} / \mathrm{cm}$. After a total of $(28+350)$ days, the three cubes were tested for their cube strengths. 


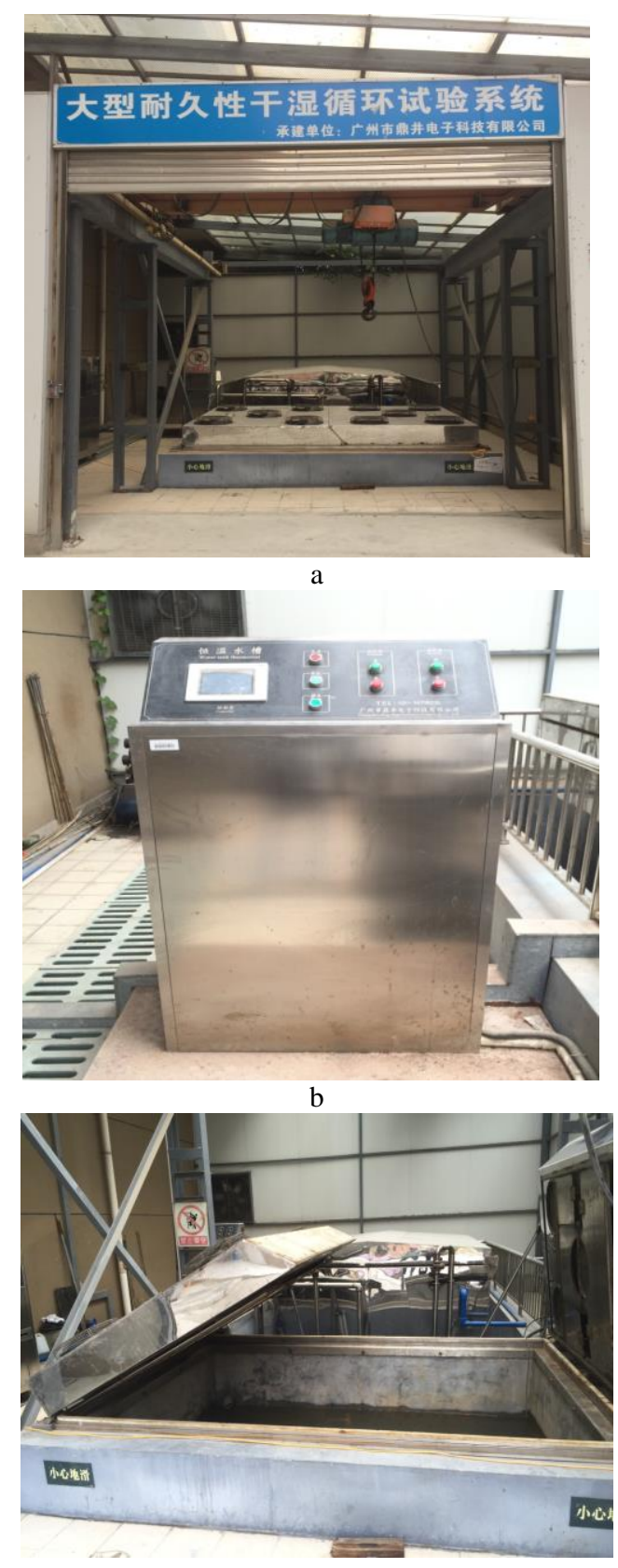

$\mathrm{c}$

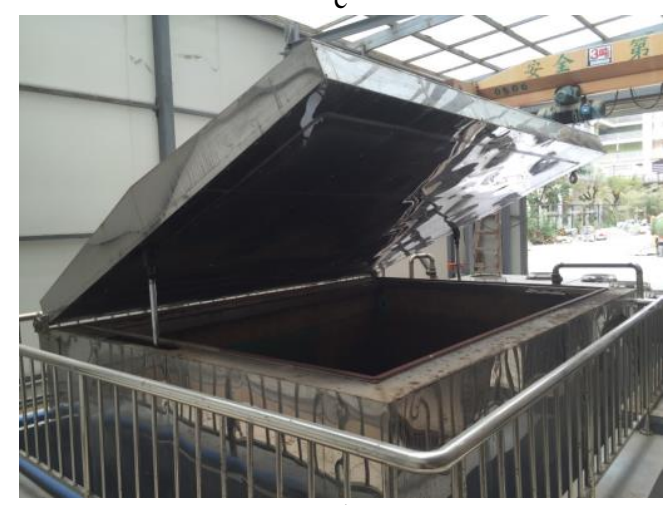

d

Fig. 7. Photographs of cyclic wetting-drying chloride attack testing machine: a-cyclic wetting-drying chloride attack testing machine; $\mathrm{b}$-control console; $\mathrm{c}$-testing chamber; $\mathrm{d}$-water tank

The strength loss, taken as a measure of the effect of seawater attack, was calculated as 1.0 minus the ratio of the average cube strength after seawater attack to the average cube strength without seawater attack, expressed as a percentage. Besides, each panel specimen was tested for the chloride profile across the depth.

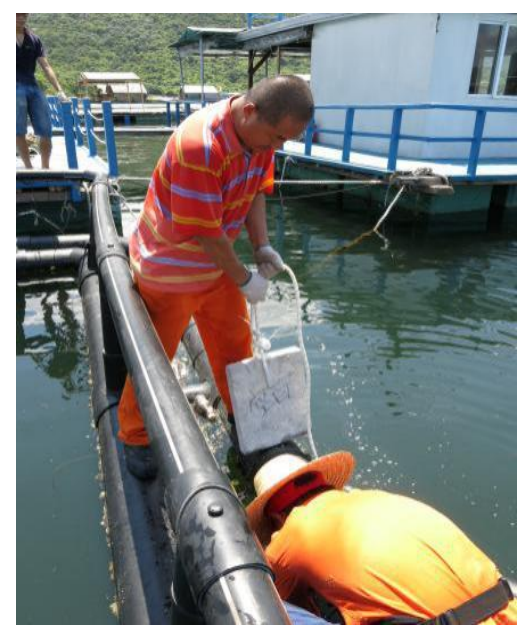

Fig. 8. Photograph of concrete panel immersion process

\subsection{Chloride profile test}

After the cyclic wetting-drying chloride attack test and long-term seawater attack test, the chloride profiles in the tested panels were measured by taking cores from the panels and determining the chloride contents at various depths. From each core taken, dry powder samples were obtained at $2 \mathrm{~mm}$ depth intervals for measuring the chloride profile across the depth. The chloride content in each dry powder sample was tested by the chemical titration method stipulated in the British Standard BS EN 196-2 (2013) [38]. From the chloride profile (variation of chloride content with depth) so obtained, the chloride diffusion coefficient was evaluated by fitting the chloride profile to equation of Fick's second law of diffusion [39].

\section{EXPERIMENTAL RESULTS OF PHASE I}

\subsection{Cube strength}

The 7-day and 28-day cube strength results are tabulated in the second and third columns of Table 4, respectively, and plotted in Fig. 9. From Fig. 9, it is obvious that the 7-day cube strengths of the concrete mixes containing COS, FA and BS were generally higher than that of the control mix C40, indicating that the addition of COS, FA and BS had slightly improved the early strength, or at least had no adverse effect on the early strength.

On the other hand, it can be seen that except for the concrete mixes C-3-1-3, C-3-2-1 and C-3-3-2, the 28-day cube strengths of the concrete mixes containing COS, FA and BS were higher than that of the control concrete mix C40, revealing that the addition of proper amounts of COS, FA and BS had positive effect on the later strength. However, it is worth noting that the 28-day cube strengths of C-3-1-3, C-3-2-1 and C-3-3-2, which all have a COS content of $20 \%$, were lower than that of $\mathrm{C} 40$ by about $8 \%$. This implies that the addition of an excessive amount of COS had a negative effect on the later strength of concrete. 


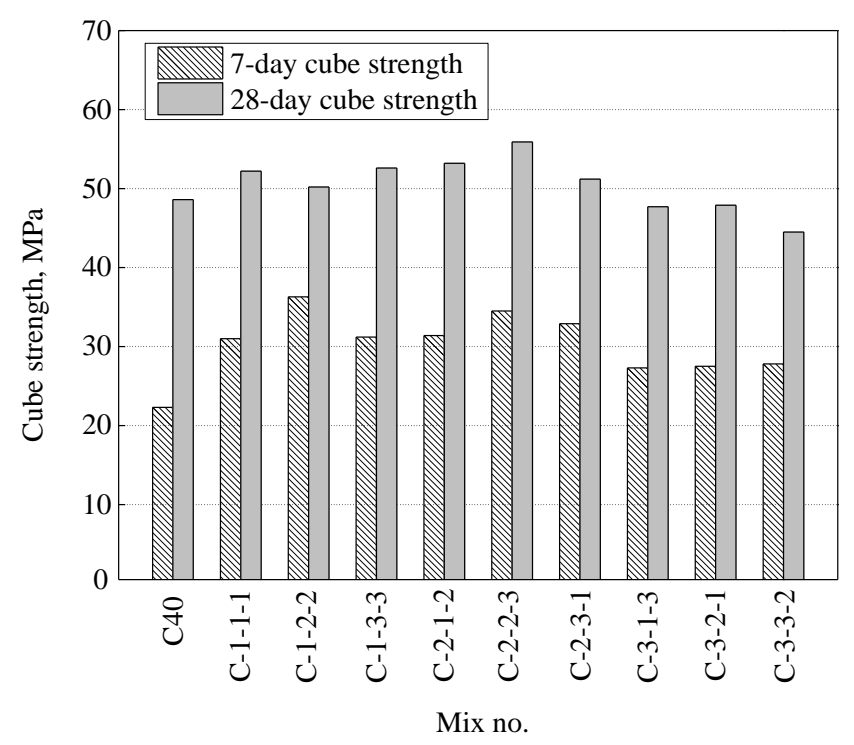

Fig. 9. Cube strengths of concrete mixes in Phase I

\subsection{Chloride profile and diffusion coefficient}

The chloride content results after cyclic wetting-drying chloride attack test are plotted against the depth from exposed surface in Fig. 10. It is seen that the chloride content decreased with depth and all the chloride contentdepth curves flatten at around $20 \mathrm{~mm}$. It is worthwhile to note that the chloride content-depth curve of $\mathrm{C} 40$ is lower than those of C-3-1-3, C-3-2-1 and C-3-3-2, but higher than those of the other concrete mixes.

To further evaluate the effects of COS, FA and BS on chloride penetration resistance of concrete, the chloride diffusion coefficient of each concrete mix was calculated, as tabulated in the fourth column of Table 4 and plotted in Fig. 11. From these results, it is evident that the chloride diffusion coefficient of $\mathrm{C} 40$ is lower than those of C-3-1-3, C-3-2-1 and C-3-3-2 (containing $20 \%$ COS) but higher than those of the other concrete mixes (containing $5 \%$ to $10 \%$ COS). This phenomenon reveals that adding proper amounts of COS, FA and BS would have positive effect on chloride penetration resistance of concrete, but adding an excessive amount of COS could have negative effect.

\subsection{Water penetration depth}

The water penetration depth results are tabulated in the fifth column of Table 4 and plotted in Fig. 11. From these results, it is noted that whilst the concrete mixes C-3-2-1 and C-3-3-2 with COS content $=20 \%$ had slightly larger water penetration depths, the other concrete mixes containing COS, FA and BS had smaller water penetration depths than that of the control mix C40. Such observed phenomenon indicates that the addition of proper amounts of COS, FA and BS generally had positive effect on the water penetration resistance but the addition of an excessive amount of COS had a negative effect on the water penetration resistance.

\subsection{Comprehensive score and range}

To find out the optimum mix proportions and systematically evaluate the effects of COS content, $(\mathrm{FA}+\mathrm{BS})$ content and FA/BS ratio on the overall performance of concrete, the comprehensive score $Y$ and range $R$ were calculated based on the orthogonal experimental design method [36].

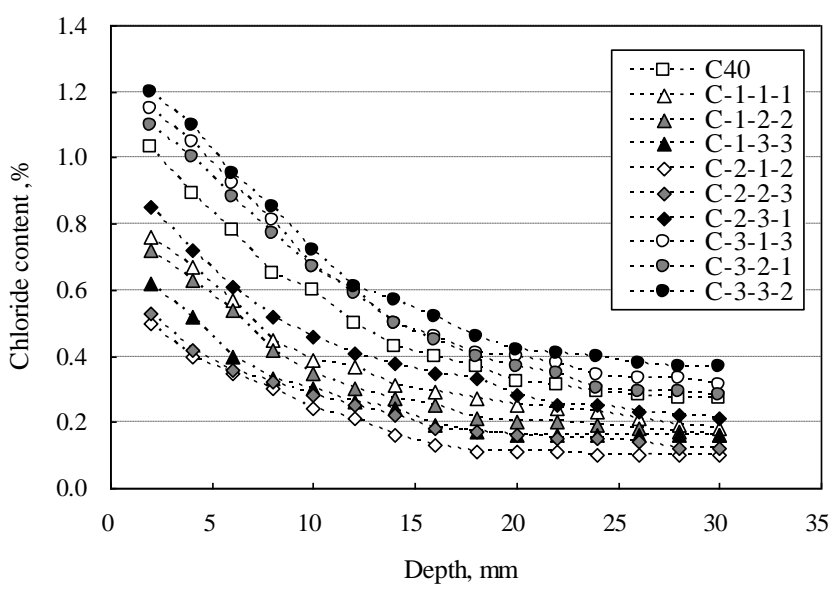

Fig. 10. Chloride profiles of concrete mixes in Phase I

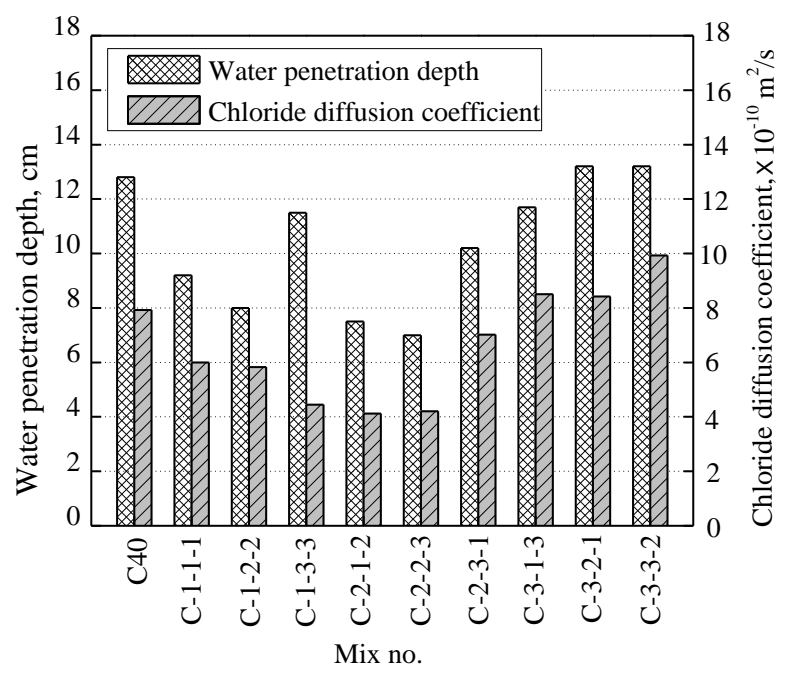

Fig. 11. Water penetration depths and chloride diffusion coefficients of concrete mixes in Phase I

Firstly, the comprehensive score $Y_{i}$ of each concrete mix can be calculated as:

$Y_{i}=10 \times \frac{a_{i}-a_{\min }}{a_{\max }-a_{\min }}+30 \times \frac{b_{i}-b_{\min }}{b_{\max }-b_{\min }}-30 \times \frac{c_{i}-c_{\min }}{c_{\max }-c_{\min }}-30 \times \frac{d_{i}-d_{\min }}{d_{\max }-d_{\min }}$

where $a_{i}, a_{\min }$ and $a_{\max }$ represent respectively the 7-day cube strength of concrete mix $i$, minimum 7-day cube strength and maximum 7-day cube strength among the nine concrete mixes; $b_{i}, b_{\min }$ and $b_{\max }$ represent respectively the 28-day cube strength of concrete mix $i$, minimum 28-day cube strength and maximum 28-day cube strength among the nine concrete mixes; $c_{i}, c_{\min }$ and $c_{\max }$ represent respectively the water penetration depth of concrete mix $i$, minimum water penetration depth and maximum water penetration depth among the nine concrete mixes; $d_{i}, d_{\text {min }}$ and $d_{\max }$ represent respectively the chloride diffusion coefficient of concrete mix $i$, minimum chloride diffusion coefficient and maximum chloride diffusion coefficient among the nine concrete mixes. Considering the different level of importance of early strength, long-term strength, water resistance and chloride resistance on marine concrete, weighting factors of $10,30,30$ and 30 were applied to the 
7-day cube strength, 28-day cube strength, water penetration depth and chloride diffusion coefficient, respectively, with a sum of 100 . The last two terms bear a minus sign for the reason that smaller values of water penetration depth and chloride diffusion coefficient indicate better concrete performance.

Table 4. Test results in Phase I

\begin{tabular}{|c|c|c|c|c|c|}
\hline Mix no. & $\begin{array}{c}7 \text {-day } \\
\text { cube } \\
\text { strength, } \\
\mathrm{MPa}\end{array}$ & $\begin{array}{c}28 \text {-day } \\
\text { cube } \\
\text { strength, } \\
\mathrm{MPa}\end{array}$ & $\begin{array}{c}\text { Chloride } \\
\text { diffusion } \\
\text { coefficient, } \\
\times 10^{-10} \mathrm{~m}^{2} / \mathrm{s}\end{array}$ & $\begin{array}{c}\text { Water } \\
\text { penetration } \\
\text { depth, cm }\end{array}$ & $\begin{array}{c}\text { Compre- } \\
\text { hensive } \\
\text { score }\end{array}$ \\
\hline $\mathrm{C} 40$ & 22.3 & 48.6 & 7.92 & 12.8 & - \\
\hline $\mathrm{C}-1-1-1$ & 31.0 & 52.2 & 6.00 & 9.2 & 64.0 \\
\hline $\mathrm{C}-1-2-2$ & 36.3 & 50.2 & 5.83 & 8.0 & 71.3 \\
\hline $\mathrm{C}-1-3-3$ & 31.2 & 52.6 & 4.45 & 11.5 & 62.2 \\
\hline $\mathrm{C}-2-1-2$ & 31.4 & 53.2 & 4.12 & 7.5 & 85.0 \\
\hline $\mathrm{C}-2-2-3$ & 34.5 & 55.9 & 4.20 & 7.0 & 97.6 \\
\hline $\mathrm{C}-2-3-1$ & 32.9 & 51.2 & 7.02 & 10.2 & 53.4 \\
\hline $\mathrm{C}-3-1-3$ & 27.3 & 47.7 & 8.50 & 11.7 & 23.1 \\
\hline $\mathrm{C}-3-2-1$ & 27.5 & 47.9 & 8.42 & 13.2 & 17.0 \\
\hline $\mathrm{C}-3-3-2$ & 27.8 & 44.5 & 9.93 & 13.2 & 0.6 \\
\hline
\end{tabular}

Using the above equation, the comprehensive score of each concrete mix was calculated, as tabulated in the sixth column of Table 4 . From these results, it can be seen that the concrete mixes C-3-1-3, C-3-2-1 and C-3-3-2, which all have COS content of $20 \%$, have the lowest comprehensive scores, implying that an excessive amount of COS would have a negative effect on the overall performance of concrete. On the other hand, the concrete mix C-2-2-3, which has COS content of $10 \%$, (FA + BS) content of $20 \%$ and FA/BS ratio of 2.0, has achieved the highest comprehensive score, indicating that this particular concrete mix is the optimum for best overall performance of concrete.

Secondly, the significance of each level of the factors $\mathrm{A}, \mathrm{B}$ and $\mathrm{C}$ are established as follows. From the comprehensive scores, the sum $S$ for each factor at each level can be calculated by adding the comprehensive scores for this factor at this level together. For example, the sum $S$ for factor $\mathrm{B}$ at level 3 can be calculated by adding $Y_{\mathrm{C}-1-3-3}$, $Y_{\mathrm{C}-2-3-1}$ and $Y_{\mathrm{C}-3-3-2}$ together, i.e. $62.2+53.4+0.6=116.2$. The sum results so obtained are tabulated in the second to fourth rows of Table 5 .

Table 5. Calculations of sum and range

\begin{tabular}{|c|c|c|c|c|}
\hline \multicolumn{2}{|c|}{ Sum and range } & Factor A & Factor B & Factor C \\
\hline \multirow{3}{*}{$S$} & at level 1 & 197.5 & 172.1 & 134.4 \\
\cline { 2 - 5 } & at level 2 & 236.0 & 185.9 & 156.9 \\
\cline { 2 - 5 } & at level 3 & 40.7 & 116.2 & 182.9 \\
\hline \multicolumn{2}{|c|}{$R$} & 195.3 & 69.7 & 48.5 \\
\hline
\end{tabular}

Finally, to evaluate the impact degree of the factors A, $\mathrm{B}$ and $\mathrm{C}$, the range $R$ for each factor was calculated as the maximum sum minus the minimum sum. For example, the range $R$ for factor $\mathrm{C}$ can be calculated as $182.9-134.4=48.5$. The range results so obtained are tabulated in the fifth row of Table 5. Comparing the three range results, it is noted that the range of factor $\mathrm{A}$ $(=195.3)$ is higher than that of factor B $(=69.7)$, and the range of factor $B$ is higher than that of factor $C(=48.5)$. Hence, factor A, i.e. COS content, has the highest impact on the overall performance of concrete, while factor $\mathrm{B}$, i.e. $(\mathrm{FA}+\mathrm{BS})$ content, comes second, and factor C, i.e. FA/BS ratio, comes third.

\section{EXPERIMENTAL RESULTS OF PHASE II}

Since it was found in Phase I that the concrete mix $\mathrm{C}-2-2-3$, which has COS content of $10 \%$, (FA + BS) content of $20 \%$ and $\mathrm{FA} / \mathrm{BS}$ ratio of 2.0 , is the optimum concrete mix, and the COS content is the most important factor affecting the overall performance. To further find out how the concrete performance varies with the COS content and henceforth to determine the optimum COS content, one control mix $\mathrm{C} 40$ and a series of concrete mixes with fixed $(\mathrm{FA}+\mathrm{BS})$ content of $20 \%$ and fixed FA/BS ratio of 2.0 but varying COS contents of $0 \%, 4 \%$, $6 \%, 8 \%, 10 \%$ and $12 \%$, were produced for 28 -day cube strength test, long-term seawater attack test and chloride profile test. The test results are presented and discussed below.

\subsection{Cube strength and strength loss}

The average 28-day cube strengths of concrete mixes without subject to seawater attack are listed in the second column of Table 6 and plotted in Fig. 12. From these results, it can be seen that the cube strength of control mix $\mathrm{C} 40$ is the lowest. More importantly, as the COS content increased from a low value to around 8 to $10 \%$, the cube strength eventually increased to the maximum, and as the COS content further increased, the cube strength started to decrease, indicating that the COS content of 8 to $10 \%$ is the optimum for maximizing the cube strength without seawater attack. Nevertheless, at a COS content of $12 \%$, the cube strength was still slightly higher than that of $\mathrm{C} 40$. Hence, although a COS content of $12 \%$ would not yield the highest cube strength, it had no adverse effect on the cube strength without seawater attack.

Table 6. Test results in Phase II

\begin{tabular}{|c|c|c|c|c|}
\hline Mix no. & $\begin{array}{c}\text { Cube } \\
\text { strength } \\
\text { without } \\
\text { seawater } \\
\text { attack, } \\
\text { MPa }\end{array}$ & $\begin{array}{c}\text { Cube } \\
\text { strength } \\
\text { after } \\
\text { seawater } \\
\text { attack, } \\
\text { MPa }\end{array}$ & $\begin{array}{c}\text { Strength } \\
\text { loss, \% }\end{array}$ & $\begin{array}{c}\text { Chloride } \\
\text { diffusion } \\
\text { coefficient, } \\
\times 10^{-10} \mathrm{~m}^{2} / \mathrm{s}\end{array}$ \\
\hline C40 & 48.6 & 36.5 & 24.9 & 4.90 \\
\hline C-0 & 50.3 & 38.5 & 23.5 & 3.94 \\
\hline C-4 & 51.6 & 42.2 & 18.2 & 2.19 \\
\hline C-6 & 52.0 & 44.0 & 15.4 & 1.02 \\
\hline C-8 & 56.2 & 48.1 & 14.4 & 0.85 \\
\hline C-10 & 55.9 & 48.0 & 14.1 & 0.82 \\
\hline C-12 & 48.9 & 39.8 & 18.6 & 4.79 \\
\hline
\end{tabular}

Likewise, the average 28-day cube strengths of concrete mixes after subject to seawater attack are listed in the third column of Table 6 and also plotted in Fig. 12. From these results, it is evident that the variation trend of average cube strength after seawater attack was similar to that of average cube strength without seawater attack. Basically, control mix $\mathrm{C} 40$ had the lowest cube strength after seawater attack, C-8 and C-10 had the highest cube strength after seawater attack. At higher COS content, C12 had lower cube strength after seawater attack than C-8 
and C-10 (but still higher than C40). Hence, the COS content of 8 to $10 \%$ is the optimum for maximizing the cube strength after seawater attack, though a COS content up to $12 \%$ had no adverse effect on the cube strength after seawater attack.

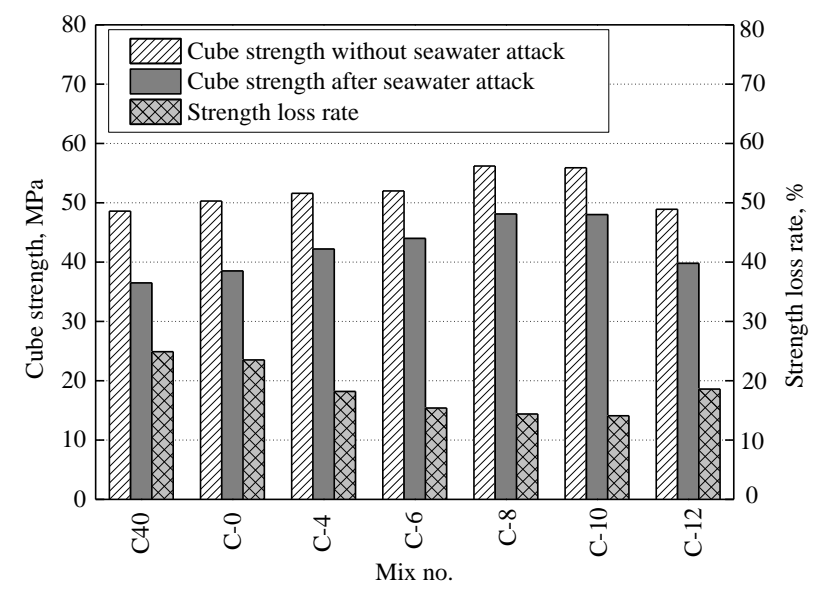

Fig. 12. Cube strengths of concrete mixes in Phase II

Comparing the average cube strength after seawater attack with the average cube strength without seawater attack, it is noted that the seawater attack always reduced the average cube strength. This was due to the corrosive effect of the seawater. To further evaluate the seawater attack resistance of the concrete, the strength losses after seawater attack were calculated, as tabulated in the fourth column of Table 6 and plotted in Fig. 12. It is evident from these results that the strength loss of C40 was the largest. More importantly, as COS was added in conjunction with FA and BS, the strength loss significantly decreased. When the COS content was increased from a low value to $10 \%$, the strength loss eventually decreased to the minimum. However, when the COS content was further increased to $12 \%$, the strength loss increased but was still smaller than the strength loss of $\mathrm{C} 40$. Hence, it is shown that the COS content of 8 to $10 \%$ is the optimum for minimizing the strength loss due to seawater attack and a COS content of $12 \%$ has no adverse effect on the seawater attack resistance.

\subsection{Chloride profile and diffusion coefficient}

The chloride content results after long-term seawater attack test are plotted against the depth from exposed surface in Fig. 13. It is noted that the chloride content decreased with depth and all chloride content-depth curves flatten at around $10 \mathrm{~mm}$. It is also noted that the chloride content-depth curves of $\mathrm{C} 40$ and $\mathrm{C}-12$ are generally higher than those of the other concrete mixes, indicating that these two concrete mixes were more vulnerable to seawater attack.

To further evaluate the effects of COS content on chloride penetration, the chloride diffusion coefficient of each concrete mix was calculated, as tabulated in the fifth column of Table 6 and plotted in Fig. 14. From these results, it is obvious that the chloride diffusion coefficient of $\mathrm{C} 40$ was the highest. As the COS content increased to around 8 to $10 \%$, the chloride diffusion coefficient decreased to the minimum values, but as the COS content further increased to $12 \%$, the chloride diffusion coefficient increased but remained smaller than that of $\mathrm{C} 40$. Hence, it is found that the COS content of 8 to $10 \%$ is the optimum for minimizing chloride penetration, and a COS content of $12 \%$ has no adverse effect on the chloride penetration resistance.

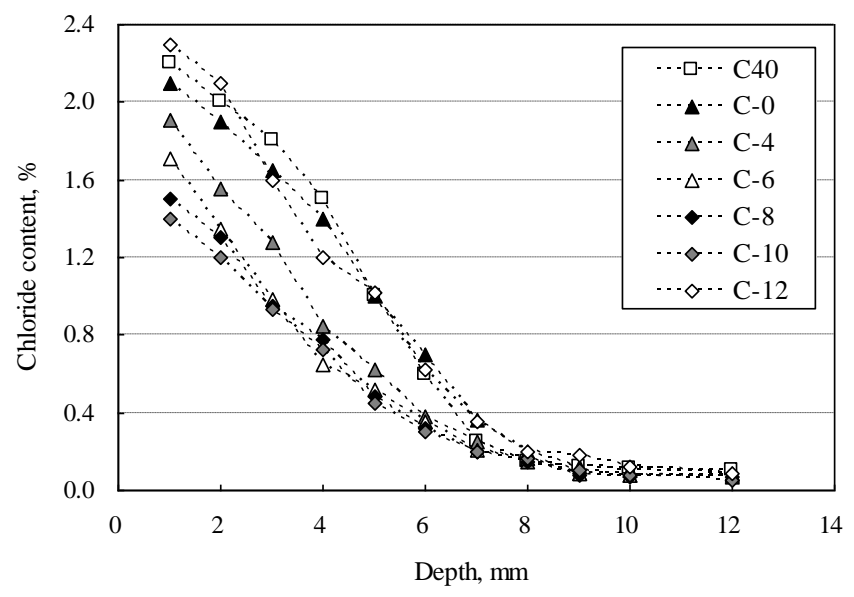

Fig. 13. Chloride profiles of concrete mixes in Phase II

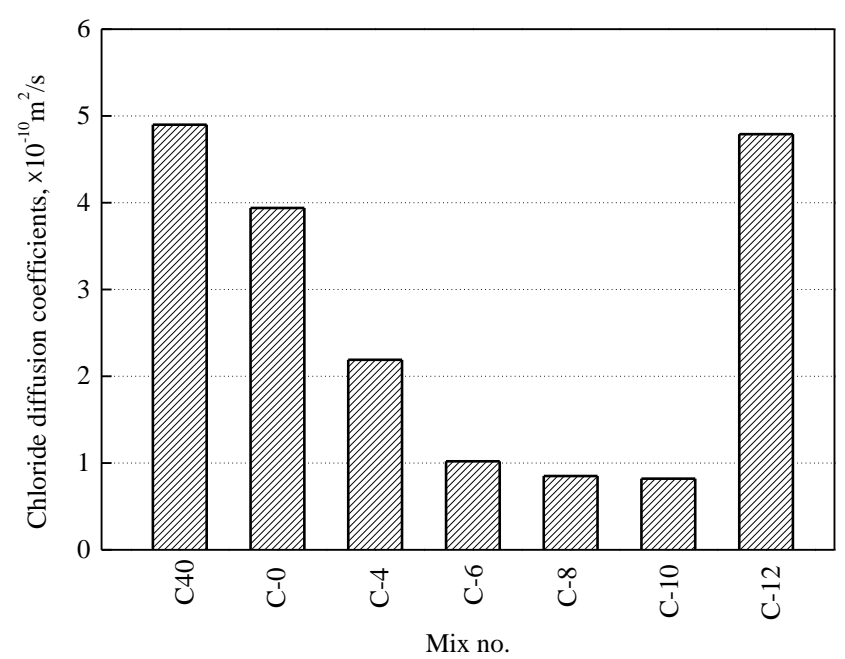

Fig. 14. Chloride diffusion coefficients of concrete mixes in Phase II

\section{CONCLUSIONS}

The feasibility of using crushed oyster shell (COS) as fine aggregate in marine concrete has been studied and the effects of adding COS, fly ash (FA) and blastfurnace slag (BS) on the strength and durability of marine concrete have been tested to find out the optimum mix proportion for best overall performance and the maximum COS content without adversely affecting the strength and durability performance of the concrete produced. Based on the test results, the following conclusions are drawn:

1. The addition of proper amounts of COS, FA and BS has positive effects on the 7-day and 28-day cube strengths, water penetration resistance, cyclic wetting and drying chloride resistance and long-term seawater attack resistance of marine concrete. However, an excessive COS content of $20 \%$ has negative effects on the 28-day cube strength, water penetration resistance and cyclic wetting-drying chloride resistance.

2. By comprehensive score and range calculations, the 
concrete mix C-2-2-3, having COS content of $10 \%$, $(\mathrm{FA}+\mathrm{BS})$ content of $20 \%$ and $\mathrm{FA} / \mathrm{BS}$ ratio of 2.0 , is found to be the optimum mix proportion for best overall performance, and the COS content is the most important factor among the three factors evaluated (COS content, FA + BS content and FA/BS ratio).

3. A COS content of 8 to $10 \%$ is the optimum for maximizing the cube strength and seawater attack resistance, yet a COS content of up to $12 \%$ has no adverse effect on the cube strength and seawater attack resistance.

Finally, it is remarked that oyster shell may be crushed for use in marine concrete not only for turning waste into a useful material, but also for improving the strength and durability performance and reducing the cost of production of marine concrete. However, it is admitted that due to limited scope of the present study, the full potential of oyster shell has not yet been exploited. Further research on the possible use of oyster shell fines with different fineness (such oyster shell fines will need to be produced by grinding) as cementitious materials replacement or cementitious paste replacement is highly recommended.

\section{Acknowledgments}

The authors gratefully acknowledge the financial support provided by National Natural Science Foundation of China (Project No. 51608131), Natural Science Foundation of Guangdong Province (Project No. 2015A030310282), Guangdong Science and Technology Planning Project (Project No. 2015A010105026), Science and Technology Planning Project of Guangzhou City (Project Nos. 201607010329 and 201704030010), Special Fund for Agro-scientific Research in the Public Interest (Project No. 201003068), National Science and Technology Ministry (Project No. 2012BAD18B02), Public Science and Technology Research Funds Projects of Ocean (Project No. 201005013-4), Featured and Innovative Project for Colleges and Universities of Guangdong Province (Project No. 2017KTSCX061), and the raw materials and testing site provided by South China Sea Fisheries Research Institute.

\section{REFERENCES}

1. Bacarji, E., Toledo Filho, R.D., Koenders, E.A.B., Figueiredo, E.P., $\quad$ Lopes, J.L.M.P. $\quad$ Sustainability Perspective of Marble and Granite Residues as Concrete Fillers Construction and Building Materials 45 2013: pp. $1-10$.

https://doi.org/10.1016/j.conbuildmat.2013.03.032

2. Finoženok, O., Žurauskienè, R., Žurauskas, R. The Influence of Crushed Concrete Demolition Waste Aggregates on the Hardening Process of Concrete Mixtures Materials Science (Medžiagotyra) 19 (1) 2013: pp. $96-102$.

https://doi.org/10.5755/j01.ms.19.1.3833

3. Penteado, C.S.G., De Carvalho, E.V., Lintz, R.C.C. Reusing Ceramic Tile Polishing Waste in Paving Block Manufacturing Journal of Cleaner Production 112 2016: pp. $514-520$.

https://doi.org/10.1016/j.jclepro.2015.06.142
4. Vaickelionis, G., Valančienė, V. Lightweight Concrete with an Agricultural Waste - Buckwheat Husk Materials Science (Medžiagotyra) 22 (1) 2016: pp. 98-104. https://doi.org/10.5755/j01.ms.22.1.8662

5. Biglarijoo, N., Nili, M., Hosseinian, S.M. Modelling and Optimisation of Concrete Containing Recycled Concrete Aggregate and Waste Glass Magazine of Concrete Research 69 (6) 2017: pp. 306-316. https://doi.org/10.1680/jmacr.16.00279

6. Lam, L., Wong, Y.L., Poon, C.S. Effect of Fly Ash and Silica Fume on Compressive and Fracture Behaviours of Concrete Cement and Concrete Research 28 (2) 1998: pp. $271-283$. https://doi.org/10.1016/S0008-8846(97)00269-X

7. Yeau, K.Y., Kim, E.K. An Experimental Study on Corrosion Resistance of Concrete with Ground Granulate Blast-furnace Slag Cement and Concrete Research 35 (7) 2005: pp. $1391-1399$. https://doi.org/10.1016/j.cemconres.2004.11.010

8. Ozkan, O., Yüksel, I., Muratoğlu, O. Strength Properties of Concrete Incorporating Coal Bottom Ash and Granulated Blast Furnace Slag Waste Management $27(2)$ 2007: pp. $161-167$. https://doi.org/10.1016/j.wasman.2006.01.006

9. Garcés, P., Andión, L.G., Zornoza, E., Bonillab, M., Payáb, J. The Effect of Processed Fly Ashes on the Durability and the Corrosion of Steel Rebars Embedded in Cement-Modified Fly Ash Mortars Cement and Concrete Composites 32 (3) 2010: pp. 204-210. https://doi.org/10.1016/j.cemconcomp.2009.11.006

10. Sim, J., Park, C. Compressive Strength and Resistance to Chloride Ion Penetration and Carbonation of Recycled Aggregate Concrete with Varying Amount of Fly Ash and Fine Recycled Aggregate Waste Management 31 (11) 2011: pp. 2352-2360. https://doi.org/10.1016/j.wasman.2011.06.014

11. Jalal, M., Pouladkhan, A., Harandi, O.F., Jafari, D. Comparative Study on Effects of Class F Fly Ash, Nano Silica and Silica Fume on Properties of High Performance Self Compacting Concrete Construction and Building Materials 94 2015: pp. 90-104. https://doi.org/10.1016/j.conbuildmat.2015.07.001

12. Lye, C.Q., Dhir, R.K., Ghataora, G.S. Carbonation Resistance of Fly Ash Concrete Magazine of Concrete Research 67 (21) 2015: pp. 1150-1178. https://doi.org/10.1680/macr.15.00204

13. Topçu, İ.B., Uygunoğlu, T., Hocaoğlu, İ. Electrical Resistivity of Fly Ash Blended Cement Paste at Hardening Stage Materials Science (Medžiagotyra) $22(3)$ 2016: pp. $458-462$. https://doi.org/10.5755/j01.ms.22.3.10771

14. Norrarat, P., Tangchirapat, W., Jaturapitakkul, C. Evaluation of Heat Evolution of Pastes Containing High Volume of Ground River Sand and Ground Granulated Blast Furnace Slag Materials Science (Medžiagotyra) 23 (1) 2017: pp. 57-63. https://doi.org/10.5755/j01.ms.23.1.13579

15. Yoon, G.L., Kim, B.T., Kim, B.O., Han, S.H. ChemicalMechanical Characteristics of Crushed Oyster-Shell Waste Management 23 (9) 2003: pp. 825-834. https://doi.org/10.1016/S0956-053X(02)00159-9

16. Kwon, H.B., Lee, C.W., Jun, S.B., Yun, J.D., Weon, S.Y., Koopman, B. Recycling Waste Oyster Shells for Eutrophication Control Resources Conservation and Recycling 41 (1) 2004: pp. 75-82. 
https://doi.org/10.1016/j.resconrec.2003.08.005

17. Li, G., Xu, X., Chen, E. Fan, J., Xiong, G.J. Properties of Cement-Based Bricks with Oyster-Shells Ash Journal of Cleaner Production 91 2015: pp. 279-287. https://doi.org/10.1016/j.jclepro.2014.12.023

18. Choi, Y.M., Whang, J.H., Kim, J.M., Suh, H.J. The Effect of Oyster Shell Powder on the Extension of the Shelf-Life of Kimchi Food Control 17 (9) 2006: pp. 695-699. https://doi.org/10.1016/j.foodcont.2005.04.005

19. Kim, Y.S., Choi, Y.M., Noh, D.O., Cho, S.Y., Suh, H.J. The Effect of Oyster Shell Powder on the Extension of the Shelf Life of Tofu Food Chemistry 103 (1) 2007: pp. $155-160$. https://doi.org/10.1016/j.foodchem.2006.07.040

20. Lee, C.H., Lee, D.K., Ali, M.A., Kim, P.J. Effects of Oyster Shell on Soil Chemical and Biological Properties and Cabbage Productivity as a Liming Materials Waste Management 28 (12) 2008: pp. 2702-2708. https://doi.org/10.1016/j.wasman.2007.12.005

21. Kwo, Y.T., Lee, C.W., Yun, J.H. Development of Vermicast from Sludge and Powdered Oyster Shell Journal of Cleaner Production 17 (7) 2009: pp. 708-711. https://doi.org/10.1016/j.jclepro.2008.11.014

22. Yang, E.I., Yi, S.T., Leem, Y.M. Effect of Oyster Shell Substituted for Fine Aggregate on Concrete Characteristics Cement and Concrete Research 35 (11) 2005: pp. $2175-2182$. https://doi.org/10.1016/j.cemconres.2005.03.016

23. Yang, E.I., Kim, M.Y., Park, H.G., Yi, S.T. Effect of Partial Replacement of Sand with Dry Oyster Shell on the Long-term Performance of Concrete Construction and Building Materials 24 (5) 2010: pp. 758-765. https://doi.org/10.1016/j.conbuildmat.2009.10.032

24. Muthusamy, K., Sabri, N.A. Cockle Shell: A Potential Partial Coarse Aggregate Replacement in Concrete International Journal of Science Environment and Technology 1 (4) 2012: pp. 260-267.

25. Nguyen, D.H., Boutouil, M., Sebaibi, N., Leleyter, L., Baraud, F. Valorization of Seashell By-Products in Pervious Concrete Pavers Construction and Building Materials 49 2013: pp. 151-160. https://doi.org/10.1016/j.conbuildmat.2013.08.017

26. Olivia, M., Mifshella, A.A., Darmayanti, L. Mechanical Properties of Seashell Concrete Procedia Engineering 125 2015: pp. $760-764$. https://doi.org/10.1016/j.proeng.2015.11.127

27. Eo, S.H., Yi, S.T. Effect of Oyster Shell as an Aggregate Replacement on the Characteristics of Concrete Magazine of Concrete Research 67 (15) 2015: pp. 833-842. https://doi.org/10.1680/macr.14.00383

28. Martínez-García, C., González-Fonteboa, B., MartínezAbella, F., Carro-López, D. Performance of Mussel Shell as Aggregate in Plain Concrete Construction and Building Materials 139 2017: pp. 570-583.

https://doi.org/10.1016/j.conbuildmat.2016.09.091

29. Wang, H.Y., Kuo, W.T., Lin, C.C., Chen, P.Y. Study of the Material Properties of Fly Ash Added to Oyster Cement Mortar Construction and Building Materials 41 (2) 2013: pp. $532-537$.

https://doi.org/10.1016/j.conbuildmat.2012.11.021

30. Thomas, M.D.A. Marine Performance of PFA Concrete Magazine of Concrete Research 43 (156) 1991: pp. $171-185$. https://doi.org/10.1680/macr.1991.43.156.171

31. Luo, R., Cai, Y., Wang, C. Huang, X.M. Study of Chloride Binding and Diffusion in GGBS Concrete Cement and Concrete Research 33 (1) 2003: pp. 1-7. https://doi.org/10.1016/S0008-8846(02)00712-3

32. Song, H.W., Saraswathy, V. Studies on the Corrosion Resistance of Reinforced Steel in Concrete with Ground Granulated Blast-Furnace Slag - An Overview Journal of Hazardous Materials 138 (2) 2006: pp. 226-233. https://doi.org/10.1016/j.jhazmat.2006.07.022

33. Chalee, W., Ausapanit, P., Jaturapitakkul, C. Utilization of Fly Ash Concrete in Marine Environment for Long Term Design Life Analysis Materials and Design 31 (3) 2010: pp. $1242-1249$. https://doi.org/10.1016/j.matdes.2009.09.024

34. Simčič, T., Pejovnik, S., Schutter, G.D., Bosiljkov, V.B. Chloride Ion Penetration into Fly Ash Modified Concrete during Wetting-Drying Cycles Construction and Building Materials 93 2015: pp. 1216-1223. https://doi.org/10.1016/j.conbuildmat.2015.04.033

35. Duan, P., Zhou, W., Yan, C. Investigation of Pore Structure and ITZ of Concrete Blended with Mineral Admixtures in a Seawater Environment Magazine of Concrete Research 67 (15) 2015: pp. 812-820. https://doi.org/10.1680/macr.14.00282

36. Taguchi, G., Chowdhury, S., Wu, Y. Taguchi's Quality Engineering Handbook. Wiley: Hoboken. 2005: pp. $584-596$. https://doi.org/10.1002/9780470258354

37. Ministry of Housing and Urban-Rural Development. GB/T 50082-2009: Standard for Test Methods of LongTerm Performance and Durability of Ordinary Concrete. China Architecture and Building Press: Beijing, 2009 (in Chinese)

38. British Standards Institution. BS EN 196-2: 2013: Method of Testing Cement: Chemical Analysis of Cement. British Standards Institution, London, 2013.

39. Valipour, M., Shekarchi, M., Arezoumandi, M. Chlorine Diffusion Resistivity of Sustainable Green Concrete in Harsh Marine Environments Journal of Cleaner Production 142 2017: pp. 4092-4100. https://doi.org/10.1016/j.jclepro.2016.10.015 